\title{
Flexible Public Spaces through Spatial Urban Interventions, Towards Resilient Cities
}

\author{
Ahmed Khaled Ahmed Elewa ${ }^{1}$
}

\begin{abstract}
Cities have become the dominant type of human settlements, currently, more than half of the planet population are living in cities. Thus, cities have to be developed not only in terms of sustainability. Cities face more challenges regarding the dealing with extraordinary events, whether they were for natural causes or terrorist attacks, socio-economic changes, in addition to the fact that climate change is responsible for new phenomena of natural disasters, such as tsunamis. The study argues that spatial urban interventions in public spaces under specific criteria can reshape them into flexible spaces that have the potentials to be adapted with extraordinary events. The study has a theoretical methodology that investigates the relations that link flexible public spaces and the achievement of urban resilience. As well as the study has a practical perspective through the analyzing of selected cases that showed how spatial urban interventions in public spaces can contribute efficiently in reshaping these spaces to be both flexible and vibrant. The findings clarified that flexible public spaces act as safety valves for our cities during extraordinary events, meanwhile, in peacetime they act as vibrant and sustainable spaces that deliver multi socio-economic and environmental functions.
\end{abstract}

\section{Introduction}

Contemporary cities represent complex socio-economic systems that tend to behave in an unforeseeable way, where they exposed to local and global influences of various aspects. According to Montenegro: 'Cities are the quintessential complex adaptive systems' (Montenegro 2010). In such a changeable context, uncertainty is strongly linked to everyday life in cities, thus cities have to be ready and to respond in an adaptive way to unexpected and unpredictable events. 'The resilience concept has become popular because of the increasing sense of uncertainty and insecurity and a search for formulas for adaptation and survival' (Christopherson et al., 2010).

Uncertainty is the product of unexpected and unpredictable events that may have a direct impact on cities, thus why it is necessary to clarify what is the intended meaning by events in this study, events refer to all the types of variables and changes that may impact the city functions, simply, events refer to extraordinary events. So these events include all types of natural and human-made disasters, crises, and other socio-economic and environmental changes, in this term, the rapid advance in information technology (IT) for instance is considered as a socio-economic change that impacts everyday life in cities. Moreover, from the time range point of view, these events are not limited to sudden ones such as natural disasters, but they also include medium and long-term events. So, the need for the achievement of resilient cities is strongly linked to the fact that cities are vulnerable to unexpected and unpredictable events. Adding to this, the statics of the World cities shows that more cities during the recent decades faced natural and terrorist attacks events, here are some key facts about cities:

- Cities already are the home of more than half of the global population, in 2018 about

| 1 Department of Architecture, Faculty of Fine Arts, Helwan University, Egypt / Associate Professor of Town planning and Architecture Design 
$55 \%$ of the global population lived in cities (UN, 2018).

- It is projected that cities will be home to $60 \%$ of the global population, and of each three people, one will live in cities with at least 500,000 inhabitants (UN, 2018).

- About $60 \%$ of the cities of the world do not any financial support for the achievement of urban resilience (Cities Alliance, 2016).

- Most cities are vulnerable to at least one type of natural disaster, According to the UN: in $201859 \%$ of the cities with at least 500,000 inhabitants were at high risk of exposure to at least one of six types of natural disaster, namely cyclones, floods, droughts, earthquakes, landslides and volcanic eruptions (UN, 2018).

- In 2018 cities of 500,000 inhabitants or more were home to 1.4 billion people already faced a high risk of exposure to at least one type of natural disaster (UN, 2018).

- It is projected by 2030 that the average loss as a result of disasters in cities could increase to more than 330 US\$ billion (Cities Alliance, 2016).

In light of the abovementioned key facts about cities currently and in the future, the seeking for the achievement of urban resilience in cities (as a crucial aim stand by the need for a sustainable development) is no more an optional decision, through the next decades it is projected that cities will be more vulnerable to damages and losses due to the population growth and assets in areas that in high risk of exposure to one of natural disaster or Political or territorial disputes and terrorist attacks. 'In the next decades, the major driver of the increasing damages and losses from disasters will be the growth of people and assets in harm's way, especially in urban areas' (World Bank, 2012). Indeed urban resilience or what is so-called resilient cities is a trending issue in the domain of urban development in both the practical realm and the academic studies.

Based on the broader understanding of events in this study, the study argues that public spaces as a fundamental and inevitable component in cities can play a key role in making cities more resilience in facing all types of events, public spaces can be used as an efficient and economic urban tool in facing the unexpected and unpredictable events in cities. This paper aimed mainly to investigate the nexus that links the achievement of urban resilience and the existence of flexible public spaces in cities. In this sense, the study conducts an analysis study that focuses on representing a specific understanding of the concepts of; Flexible public spaces, spatial urban intervention, and resilient cities, from an urban perspective. The study monitors resilient cities as an urban concept in both academic studies and in practical urban development plans, As well as to broad the scope of the urban resilience concept in cities to be not only limited to the sudden disasters, but to include all the types of unpredictable and unpredictable events, for instance the long-term socio-economic changes that impact the cities functions in negative way, particularly in the case of developing and emerging countries. Thus the study discussed the following questions:

- What is the intended meaning by the comprehensive understanding of resilience cities?

- What is the intended meaning of a flexible urban space?

- What is the nexus between urban resilience and the existence of flexible public spaces?

- What is the role of spatial urban interventions in shaping efficient flexible public spaces? 


\section{Resilient Cities, a More Comprehensive Understanding}

The definition of resilient cities in this study is strongly linked to the understanding of the event as it was described in the introduction. Events in this study have a broader understanding, they refer to all the types of extraordinary events as it was mentioned by Müller (Müller, B., 2011). Cities are always vulnerable to various events that are unpredictable and unpredictable. So resilient cities in this study refer to a more comprehensive understanding, in which resilient cities are those cities that managed to achieve an urban resilience capacity to face all the types of the unpredictable and unpredictable events. However, before defining the intended meaning by resilient cities, there is a need to track the origin of the term resilience for a more specific and comprehensive understanding of urban resilient or what is so-called resilient cities. The term resilience originates from a Latin verb that means to bounce back (Petal, R. and Nosal, L., 2016), in other words, to return to a steady-state equilibrium (Romero-Lankao, P. et al, 2016). This understanding of the term is widely used in various scientific disciplines, in which resilience describes a system's response to influence or a shock (Vale, L., 2014). Moreover, it is in line with the roots of the term in ecology, physics, material sciences, mathematics, and engineering domain, in which resilience describes the system's response to influence or a shock (Romero-Lankao, P. et al, 2016).

In light of the reached understanding of the term resilience, urban resilience can be initially defined as the capacity of an urban system to absorb disturbance, this includes all the types of extraordinary events, and to continue delivering their socio-economic functions, while undergoing change, urban resilience concept as it was described in this initial definition is widely accepted among academic literature through more than two decades and still in line with the latest contemporary definitions, however, the concept of urban resilience in theses definitions is commonly linked to the exposure to sudden events (The URBES project, 2014), while in this study urban resilience is not limited to sudden events, but it goes beyond to include even the medium and long-term changes, such as the socio-economic changes in terms of time range, further it is not limited to the events that have a negative impact on urban communities, for example, the rapid advance in information technology (IT) as a socio-economic change has positive impacts on urban communities. Here are some selected definitions that can be categorized into two groups, the first group reviews definitions that mentioned cities as the intended domain of resilience or what is so-called resilient cities. The second group reviews definitions that defined the term resilience in which resilience refers to resilience in an urban system or urban communities. See table 1.

Table 1: Comparison between the definitions of resilient cities and definitions of the term resilience, Data source, Zhang, x. \& Lid, H. 2018. Edited by author

\begin{tabular}{ll|ll} 
Author (year) & $\begin{array}{l}\text { Group A: Reviews definitions that } \\
\text { mentioned cities or what is so-called } \\
\text { resilient cities }\end{array}$ & Author (year) & $\begin{array}{l}\text { Group B: Reviews definitions that } \\
\text { defined the term resilience }\end{array}$ \\
\hline $\begin{array}{l}\text { Alberti et al. } \\
\text { (2003) }\end{array}$ & $\begin{array}{l}\text { The degree to which cities } \\
\text { tolerate alteration before } \\
\text { reorganizing around a new set of } \\
\text { structures and processes" }\end{array}$ & $\begin{array}{l}\text { Pickett, S. T. "the ability of a system to adjust in the } \\
\text { A., et al., } \\
\text { (2004) }\end{array}$ & \\
\hline
\end{tabular}




\begin{tabular}{|c|c|c|c|}
\hline $\begin{array}{l}\text { Campanella } \\
\text { (2006) }\end{array}$ & $\begin{array}{l}\text { "The capacity of a city to rebound } \\
\text { from destruction" }\end{array}$ & $\begin{array}{l}\text { Hamilton, } \\
\text { W., (2009) }\end{array}$ & $\begin{array}{l}\text { "the ability to recover and continue to } \\
\text { provide their main functions of living, } \\
\text { commerce, industry, government and } \\
\text { social gathering in the face of calamities } \\
\text { and other hazards" }\end{array}$ \\
\hline $\begin{array}{l}\text { Lamond and } \\
\text { Proverbs } \\
(2009)\end{array}$ & $\begin{array}{l}\text { "Encompasses the idea that towns } \\
\text { and cities should be able to recover } \\
\text { quickly from major and minor } \\
\text { disasters" }\end{array}$ & $\begin{array}{l}\text { Wardekker, J. } \\
\text { A., et al., } \\
(2010)\end{array}$ & $\begin{array}{l}\text { "a system that can tolerate disturbances } \\
\text { (events and trends) through } \\
\text { characteristics or measures that limit } \\
\text { their impacts, by reducing or } \\
\text { counteracting the damage and } \\
\text { disruption, and allow the system to } \\
\text { respond, recover, and adapt quickly to } \\
\text { such disturbances" }\end{array}$ \\
\hline $\begin{array}{l}\text { Lhomme et } \\
\text { al. (2013) }\end{array}$ & $\begin{array}{l}\text { "The ability of a city to absorb } \\
\text { disturbance and recover its } \\
\text { functions after a disturbance" }\end{array}$ & $\begin{array}{l}\text { Ernstson et } \\
\text { al. (2010) }\end{array}$ & $\begin{array}{l}\text { "To sustain a certain dynamic regime, } \\
\text { urban governance also needs to build } \\
\text { transformative capacity to face } \\
\text { uncertainty and change" }\end{array}$ \\
\hline $\begin{array}{l}\text { Thornbush et } \\
\text { al. (2013) }\end{array}$ & $\begin{array}{l}\text { "A general quality of the city's } \\
\text { social, economic, and natural } \\
\text { systems to be sufficiently future- } \\
\text { proof" }\end{array}$ & $\begin{array}{l}\text { Tyler and } \\
\text { Moench } \\
(2012)\end{array}$ & $\begin{array}{l}\text { "Encourages practitioners to consider } \\
\text { innovation and change to aid recovery } \\
\text { from stresses and shocks that may or } \\
\text { may not be predictable" }\end{array}$ \\
\hline $\begin{array}{l}\text { OECD, } \\
(2016)\end{array}$ & $\begin{array}{l}\text { "Resilient cities are those able to } \\
\text { absorb, adapt, transform and } \\
\text { prepare for past and future shocks } \\
\text { and stresses to ensure sustainable } \\
\text { development, well-being, and } \\
\text { inclusive growth. Resilience is made } \\
\text { up of seven building blocks" }\end{array}$ & $\begin{array}{l}\text { Desouza and } \\
\text { Flanery } \\
(2013)\end{array}$ & $\begin{array}{l}\text { "ability to absorb, adapt and respond } \\
\text { to changes in urban systems" }\end{array}$ \\
\hline $\begin{array}{l}\text { ICLEI, } \\
(2017)\end{array}$ & $\begin{array}{l}\text { A 'Resilient City' is prepared to } \\
\text { absorb and recover from any shock } \\
\text { or stress while maintaining its } \\
\text { essential functions, structures, and } \\
\text { identity, as well as adapting and } \\
\text { thriving in the face of continual } \\
\text { change. }\end{array}$ & $\begin{array}{l}\text { Romero- } \\
\text { Lankao and } \\
\text { Gnatz (2013) }\end{array}$ & $\begin{array}{l}\text { "A capacity of urban populations and } \\
\text { systems to endure a wide array of } \\
\text { hazards and stresses" }\end{array}$ \\
\hline $\begin{array}{l}\text { Evans, M., } \\
\text { (2019) }\end{array}$ & $\begin{array}{l}\text { "Resilience refers to equipping } \\
\text { cities to face future shocks and } \\
\text { stresses from climate change and } \\
\text { depleted oil and fuel sources-and } \\
\text { make it through crises" }\end{array}$ & $\begin{array}{l}\text { Romero- } \\
\text { Lankao, P., } \\
(2016)\end{array}$ & $\begin{array}{l}\text { "urban resilience is the ability of an } \\
\text { urban system to cope with impacts, } \\
\text { thin to adapt with it and take advantage } \\
\text { of opportunities" }\end{array}$ \\
\hline
\end{tabular}

The above table shows clearly that both the groups of definitions share a common sense regarding the understanding of what is the intended meaning by urban resilience or resilient cities. They share the same consensus regarding bridging the achievement of resilience in cities to the necessity of the existence of a system that has the ability to cope, absorb, bounce back, adapt, adjust, rebound to/with extreme extraordinary events, and other economic, social and environmental shocks and disasters that often have a negative impact on cities. Indeed there is consensus on the concept of urban resilience as it was described in the initial definition. 


\section{Public Spaces as Arenas for Urban Resilience}

Public spaces from an urban perspective have attracted the attention of academic research through the last three centuries, accordingly, it can be considered as a basic domain in urban studies that came early into practice during the $19^{\text {th }}$ century in UK, which witnessed the birth of the Garden City movement which linked the improving of the human well-being to the accessibility to green public spaces (Howard, E., 1898), as well as the rise of the concept of improving the quality of urban life of the working class by the existence of public open spaces in the UK and the USA. (GilesCorti, B., et al, 2005), (Jayakody, C., et al., 2016). This concept of the role of public spaces in improving the quality of urban life and human well-being is still accepted in both academic studies and practice. There is a consensus on the crucial role of public spaces as an inevitable spatial urban component that contribute positively to the socioeconomic and environmental aspects of the urban life in cities (Lynch, 1960), (Bacon, 1976), (Madanipour, A., 1996), (Cybriwsky, 1999), (Chiesura, 2014), (Sanei, M., et al, 2018). No dought that public spaces have a key role in three main domains; social, economic and environmental which form the major pillars of urban sustainability, Cybriwsky stated that "Public spaces have an important role regarding the environmental, economic, social context in the city as well as sources or providers of life quality and sustainability"(Cybriwsky, 1999), however, cities have to be developed not only in terms of sustainability, cities as complex systems in a global context that is witnessing increasing sense of uncertainty and the exposure to various unexpected and unpredictable extraordinary events have to be resilient to cope and survive in such a changeable context (Christopherson et al., 2010), (Polko, A., 2012). According to Müller regarding the term resilience and the need for it in cities" Financial crisis, political disturbance, other extraordinary events and especially the international debate about the possible environmental disaster caused by climate change have a strong influence on the popularization of the term" (Müller, 2011).

In this sense, it is rational to consider public spaces as arenas for the achievement of urban resilience in cities, in other words, public spaces through their crucial role in cities can be considered as urban domains for spatial urban intervention that contribute to urban resilience in its broader understanding that include all the type of extraordinary events, accordingly, the main argument of this study is in line with this understanding, however, this argument generate a basic question regarding how public spaces can contribute to the achievement of resilient cities. Accordingly, many recent academic studies noted the answer to this question, there is a widely accepted concept that in order to make cities resilient to extraordinary events, there is a need to use urban intervention solutions as a design approach that focus on the spatial urban components of the city, this include all the types of public spaces (Allen, P., and Bryant, M., 2010), (Fuentes, C., and Tastes, M., 2015), (Jayakody, C., et al., 2016), (Jayakody, C., et al., 2018), in other words, there is a strong relationship that links the achievement of urban resilience with the existence of high-quality open spaces network (Project for Public Spaces, 2009), high quality here refers to a specific criteria of the open spaces. Furthermore, and in line with the contemporary accepted concept of the strong linkage between urban resilience and public space, Allan and Bryant considered public spaces as a 'second city' during extraordinary events," after a major earthquake, open spaces within the city act as a 'second city' 
using the spaces for simple to complex services such as gathering, building shelters, distribution of goods and service, temporary inhabitation, and commemoration" (Allan, P. And Bryant, M., 2010). Simply

Accordingly, in this sense public spaces are not limited to open public spaces such as parks, pedestrians' network and plazas, but it also includes streets, squares and any other urban voids that considered as spatial components of the city and main while full access to the citizens of the city, So, public spaces in this study does not include semi-public spaces and of course private spaces, as well as it does not include inner public spaces that exist inside public buildings such as shopping malls. Woolley described this point of view, in which public space refers to any urban space wither green or civic spaces, but must be accessible to the public, moreover, these spaces should be outdoor, and not inside buildings such as the inner courts and atriums in shopping malls (Woolley, H., 2006). Also, Carmona emphasizes this understanding of public spaces that are capable to be used for the achievement of urban resilience in cities, he raised two basic features; the necessity of accessibility and the use pattern. Since these spaces will be used by the public during extraordinary events to enhance urban resilience. In other words, there is a need to pay more attention to public spaces that are open, accessible and can be used by the public (Carmona, m., 2010). Moughtin classified public spaces into four types; the first type includes all the categories of streets network, streets, boulevards and promenades, the second type squares and plazas, the third type include all the categories of parks or green public spaces, and the last type include the urban spaces along the waterfronts inside cities such as rivers and canals (Moughtin, C., 2003). Thus, in light of the above discussion it is clear that there is a specific criterion for public spaces to be arenas for the achievement of resilient cities, in other words, public spaces need to be designed through a specific urban intervention to obtain the capability to cope with extraordinary events and to contribute to the achievement of urban resilience in cities.

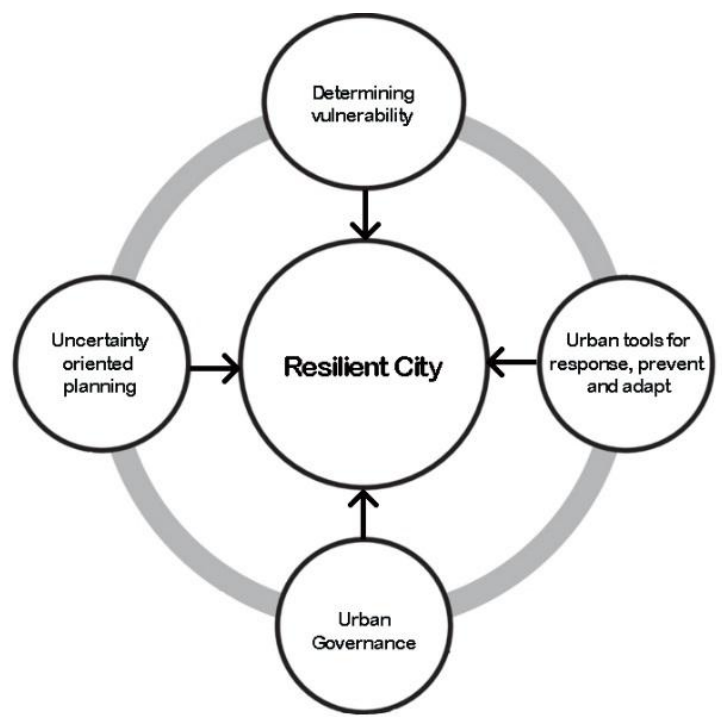

Figure 1: The need for public spaces as arenas for urban resilience, which represented in this figure as urban tools for a response, prevent and adapt. 


\subsection{The need for flexibility in public spaces to cope with extraordinary events}

Actually there is a deep similarity between the definition of flexibility from urban perspective and urban resilience, according to the previous discussion regarding the intended understanding of urban resilience, urban flexibility in public space is strongly linked to the achievement of urban resilience in cities, since flexibility can be initially defined as the ability of a system to adapt or respond to changes in the environment (Beirão, J., 2011), Indeed, there are many detentions of flexibility that meet the same reached initial understanding, for instance; the UNISDR defined flexible ecosystem or society as: "the system's ability or society at risk to resist internal and exterior risks, and also to recover from risks at certain times with efficient behaviors including structure maintenance and infrastructural performances and an attempt to repair them"(UNISDR, 2010), this definition illustrate the similarities that link both flexibility and resilience, both of them share the same base concept in which a system shows an ability to cope and adapt with changes, moreover, here is another definition in line with this understanding: "Flexibility, in general, means a change in the system and making the possibility of obtaining new conditions, needs, and frameworks" (Ardeshiri, M., et al, 2016). Furthermore, urban flexibility is considered as one of the drivers of urban resilience, according to the (OECD): "A flexible urban system allows individuals, households, businesses, communities, and government to adjust behavior or action to respond rapidly to change" (OECD, 2016).

Thus why flexibility in public spaces is a necessity and can be considered as a basic inevitable feature not only in order to build their capacity to cope and adapt with extraordinary events but also in terms of improving both physical and functional features (Sanei, M., et al, 2018). Therefore, to understand why flexibility should be considered as an initial and basic factor in designing public spaces for urban resilience, the study discusses the following questions;

- First, the need to explore the intended meaning by flexible public spaces in this study and How Fixable urban public space could increase resilience and decrease vulnerability? - Then to determine how to make public spaces flexible through urban intervention?

\subsubsection{Flexibility from an urban perspective and its nexus to urban resilience}

In general, the term flexibility refers to a system capability of being nonsensitive, bending, variability to various changes and modifications, to be ready and having the capacity for compatibility and adaptation with different conditions (Till and Schneider, 2005). (Sanei, M., et al, 2018). In urban studies domain flexibility have the same general understanding, the need for flexibility in urban design is gaining more attention in recent decades, since contemporary urbanism witness continues variables and changes, and simply change is inevitable in contemporary urban societies. Jacobs clarified this fact earlier in his book entitled "The Death and Life of Great American Cities", he highlighted the importance of urban flexibility in cities as it represents a survival tool, in other words, cities that managed to survive and to sustain are those which were physically designed to have the ability to be efficiently corrected under the impact of basic changes in functions patterns (Jacobs, J., 1961). In this sense, public spaces as arenas for everyday life in cities have to deliver appropriate responses for such changes, and to ready for any extraordinary event as urban tools that support city resilience (Khodadad and Sanei, 2017). 
From urban perspective flexibility specifically in urban design describes innovative and creative spatial adaptability that contribute to the achievement of public urban spaces that have the capacity to be organized and changed to adapt with new conditions, as well to deliver new adaptable urban solutions and applications (Sanei, M., et al, 2018), in line with this understanding Turan defined flexibility of an urban environment as its capacity to adapt to changes made by users, while flexibility of the urban environment refers to its readiness to respond to users' impact (Turan, MH., 2016). Moreover, some definitions linked directly urban flexibility in public spaces with the attracting with uncertainty which has a strong nexus with resilience concept, for instance, flexibility was described as a connector that links urban space with its outdoor environment to attract non- certainty, system dynamic degree, as well as adaptation and changeability (Ardeshiri, et al, 2016). Thus, urban flexibility can be considered as a strategic urban tool which allows optimal use of available urban resources such as public spaces and enables them to meet both the usual needs of cities and the unexpected needs that may appear during extraordinary events (Sanei, M., et al, 2018). This means that a flexible public space has the capacity to absorb disturbance (that may be caused by users) and to continue delivering their common and new functions at the same time. Hence, more public space is responsive and adaptive to changes, the higher flexibility it has to cope with those changes (Sanei, M., et al, 2018), in other words, the higher resilience it has to cope with extraordinary events. Here it is rational to link this concept with the possibility to achieve urban resilience through flexible public spaces, where the term resilience can somehow be replaced with the term flexibility as they share the same understanding. However, urban flexibility in public spaces does not refer only to its ability to cope with extraordinary events in terms of achieving urban resilience and moreover, it should be stressed that that flexibility in those public spaces was designed to act as the second city for temporary use as a main design's aim.

\subsection{Spatial urban intervention in public spaces, towards flexible public spaces}

The achievement of flexibility in public spaces for making cities resilient needs some prerequisites, as well as to make consideration of the principals for designing a flexible public space, this means that there is a crucial need for urban intervention and in particular spatial urban intervention that focus mainly on the spatial urban elements in cities, Thus in order to make cities resilient to extraordinary events such as natural disaster through spatial urban intervention, the consideration needs to be focused on public spaces (Jayakody, C., et al., 2016), public spaces through its spatial potentials can act as an urban proactive tool that contribute to solve current and futures issues such as to cope with extraordinary events at multi-scale levels with the entire city, however, this needs to be through urban planning and spatial urban interventions (Moreno, v., et al, 2014).

Public spaces from a broader understanding as it was determined before are the main spatial element that should be the focus of urban design programs. In fact, and from a practical point of view, making cities resilient needs the action of maximizing the key role of urban design that often provides creative and efficient urban solutions (UNISDR, 2012). However there is still a need to determine the perquisites and principals of flexible public spaces to apply the suitable urban intervention approach, since urban interventions related 
to all the terminologies that deal with the enhancement and redevelopment of the urban context, this include regeneration, renewal, rehabilitation, revitalization, restructuring, requalification, and restoration. (Costa, A., 2006), (Elewa, A., 2019).

\subsubsection{The design criteria to achieve flexibility through the spatial urban intervention}

The design criteria for flexible public spaces reflects the conditions of both the common everyday socio-economic activities and the temporary use as arenas for urban resilience during extraordinary events, therefore, there is a need to follow the principles of both flexible and resilience urban planning, in fact, and from urban studies point of view both resilience and flexibility have many shared bases, in which achieving flexible public space means to achieve a public space that has the capacity to contribute efficiently to urban resilience. Resilience urban planning based on three main aspects of preventing, response and finally post-disaster measures (Fallah, m., et, al, 2014), in other words, and in line with the same concept designing flexible public spaces for disaster resilience focuses on three main domains to the extraordinary events; emergency, response, recovery and mitigation (Jayakody, C., et al., 2016). Thus the design principles to achieve flexible public spaces for urban resilience is a combination of both; design principles for urban flexibility and urban resilience, these principles and perquisites include the following:

- The use of flexible public spaces as a strategy for urban resilience in a city and to act as a second city during extraordinary events needs to be designed on the scale of the entire city, in other words to deal with flexible public spaces as a network and not as individual cases (Fuentes, C., and Tastes, M., 2015), (Allan, P., and Bryant, M., 2010).

- The design process of these spaces need to be through a participatory approach in which the society participates in the design process, the spatial urban intervention can provide a participatory approach that helps in providing a flexible dynamic public space which easily can be adapted to a variety of functions that contribute to the sustainability and resilient of the city.

- These spaces need to be designed to sustain during extraordinary events, there is a need for a smart infrastructure that can provide electricity and water supply during emergency times.

- A flexible public space for urban resilience must be permeable, this means more than just to be accessible to the public, but to be available to public users in terms of giving them the rights of selection, moreover to be well-connected physically and functionally with its urban context (Ardeshiri, et al, 2016), (Fallah, m., et, al, 2014).

- In such public spaces it is important to have legibility, this means that space has a clear image that enables the users to easily understand and perceive place typology and what happens there (Ardeshiri, et al, 2016). According to Bentley Legibility is the quality that helps one space to be perceived (Bentley et al., 2003), this feature is crucial during extraordinary events, as the public users can easily recognize the space.

- This type of space needs to be smartly designed in order to be easily adapted to new spatial arrangements during extraordinary events, for instance, the possibility to expand more open space during an emergency and to hold any unexpected use (Sanei, M., et al, 2018). 


\section{Practical Cases}

The two selected cases represent a review of practical cases that illustrates the validity of the study's arguments. Where a flexible public space that was designed through a spatial urban intervention can contribute efficiently to the making of a resilient city.

\subsection{Water squares, the case of Benthemplein, Rotterdam, The Netherlands}

This case is located in The Netherlands, in Rotterdam its second-largest city and the largest port in Europe. The city as a delta city that is only around 9 meters above sea level is vulnerable to various types of extraordinary events that are related to the higher sea and river levels due to the climate change, this means increasing the risk of frequency of flooding in the outer-dike areas of the city, in addition to the depth of flood inundations (Moraci, et al, 2017). The city authorities realized the urgent need for the achievement of a resilient city in order to be saved and to have the capacity to be completely responsive and adaptive to any extraordinary events related to the climate change. Thus the city launched its adaptation program, Rotterdam Climate Proof (RCP) that aims to make Rotterdam a full climate resilient by the year 2025 (Molenaar, A., Gebraad, C., 2014), (Moraci, et al, 2017). This adaption program is based on several initiatives related to the achievement of urban resilience through the potentials of urban elements such as public spaces that include open spaces, sidewalks, riverbanks, squares, plazas, and even private open spaces such as roofs and courtyards. The innovative concept of the water squares is one of the main pillars of the resilience program (Rotterdam Municipality, 2008).
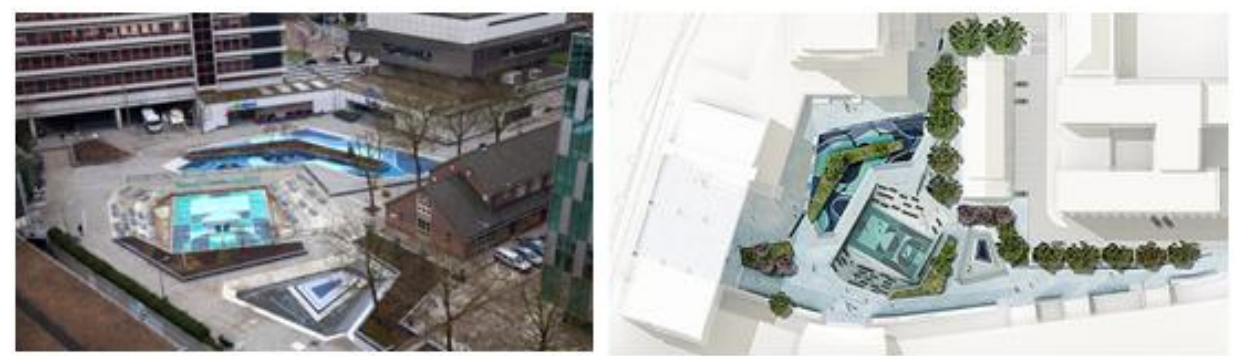

Figure 2: Left, the Benthemplein water square and its urban context, right, the project layout, source: DE URBANISTEN, 2013, and Zimmer, L, 2014.

\subsubsection{Flexible public spaces through spatial urban intervention for urban resilience and sustainability}

The case illustrates the use of the water squares as a responsive and adaptive urban tool particularly to the stormwater and floods events, 'connecting water and adaptation with opportunities'. (Molenaar, A., Gebraad, C., 2014). Benthemplein is a unique interesting example of what is so-called water squares, the project occupies an irregular urban public space surrounded by community amenities that form a cultural social hub, the site includes a church, a college, a youth theatre and gym (Wilkinson, T., 2017). The project was implemented in 2013, to be the first and largest water square, and moreover, it is a 
flexible public space that was well designed through spatial urban intervention, it is an integrated design approach that supports the community participatory during the design process. According to the design team the project was designed in an intense participatory trajectory with the local community we jointly conceived ideas about the square (DE URBANISTEN, 2013).

Thus the spatial intervention design combined between water resilience requirements, and the community needs through an interesting design that introduces multi-functional benefits. The water square combines water storage with the improvement of the quality of urban public space (DE URBANISTEN, 2013), as flexible public spaces the project have a twofold strategy, it response to the risk of stormwater, adapt with it through water storage facilities that as well contribute to a more dynamic and enjoyable space. A flexible public square doubles as water collection and storage space during periods of high rainfall (Wilkinson, T., 2017). Moreover, and according to the design team, it also generates opportunities to create environmental quality and identity to central spaces in neighborhoods. Most of the time the water square will be dry and in use as a recreational space (DE URBANISTEN, 2013), and thus why the water square include various recreational activities that take place in the square when it is dry, it include a sunken sports court offers recreation and sports facilities as to the students, Surrounded by gradated layers of stadium-style bleachers, the square can host both competitive and leisure sports (Zimmer, L, 2014). While in very wet weather it turned into a pool fed by stormwater from the surrounded area (Wilkinson, T., 2017).
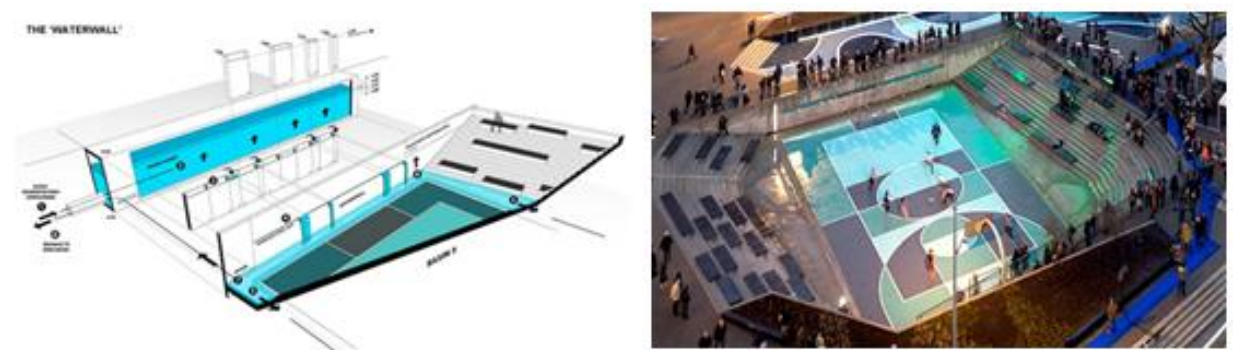

Figure 3: left, cross-section shows the mechanism of water storage in the water square, right, the square is used as a playground most of the time (when it is dry), source: DE URBANISTEN, 2013, and Zimmer, L, 2014

\subsubsection{Learned lessons}

The case study showed the validity of the theoretical hypothesis of the study, where flexible urban spaces through spatial urban intervention contribute to the achievement of a resilient city, moreover, they contribute to the enhancement of the quality of life in the city and to ensure community sustainability in terms of socioeconomic and environmental aspects. Furthermore, the case represents the following lessons from practice:

- The city of Rotterdam through its climate resilience initiative managed to develop the water squares which considered as new innovative urban tools that addressed the entire domain of water urban resilience, both to be responsive through the mitigation of the climate change impact and to be adaptive through the achievement of urban resilience (Moraci, et al, 2017). 
- Water square Benthemplein is not only a flexible public space for urban resilience it also acts as an oasis inside the dense urban context of Rotterdam, but the square is also permeable, accessible and attractive to all the community members, (Zimmer, L, 2014). Simply it is a clear example of what a flexible public spaces through spatial intervention looks like. The public space was designed through a participatory approach that allowed the community to share their ideas, needs with the designers

- The water square case clarified the strong linkage that links the potentials of flexible public spaces with the achievement of both urban resilience and sustainability.

\subsection{From airport to a vast flexible public space, the case of Tempelhof Park}

This case is about a former airport that transformed into a vast flexible public space in the heart of Berlin the capital city of Germany, Tempelhof Field was an airport in Berlin until it was closed in 2008 (Dumiak, M., 2014), the former airport located $5 \mathrm{~km}$ to the south of the city, with an oval-shaped area of 909 acres (The URBES project, 2014). Such a vast open space inside the urban context gave Berlin a variety of opportunities and potentials to use the site as City Park that can contribute to both urban resilience and sustainability. According to the Senate Department for Urban Development and Environment (SDUDE): The closing of Tempelhof Airport gave Berlin a unique opportunity to develop an inner-city parkland of extraordinary dimensions (SDUDE, 2012).

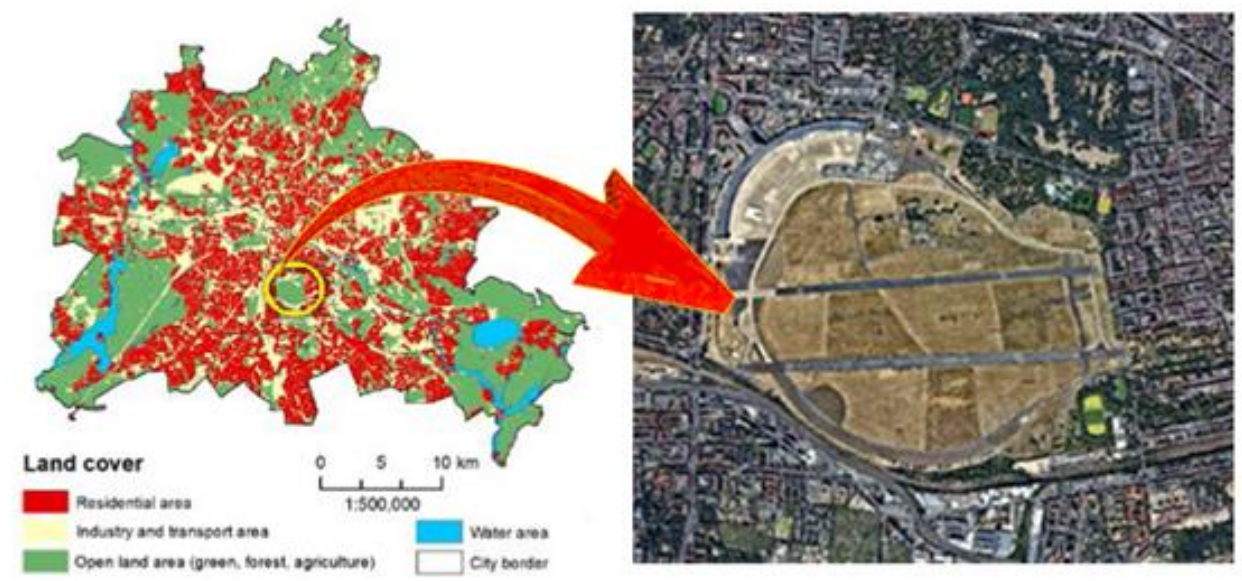

Figure 4: The location of the former Tempelhof airport inside the residential urban context of Berlin and its vast area, source The URBES project, 2014, edited by author

In March 2010, the SDUDE held an international competition that aims to make a landscape design and realization of the Tempelhof, the completion decision was a response to the community of Berlin, from the outset the people of Berlin were closely involved in the development process (SDUDE, 2012), which was to keep Tempelhof without any major changes as it right now a public park with minimal design and no development (Dumiak, M., 2014). In August 2010 the SDUDE invited the community stakeholders to discuss the selected schemes and to participate in the final decision of the parkland design (SDUDE, 2012). 


\subsubsection{Flexible public spaces through spatial urban intervention for urban resilience and sustainability}

Berlin like many cities have started to give attention to the need for urban resilience and sustainability in the context of specific locations such as the case of the former airport of Tempelhof that can contribute to both urban resilience and sustainability as a flexible public space. Flexibility, in this case, is generated as the parkland was designed as an open and accessible public space that host various functions and activities, meanwhile the green open spaces areas that were left without any modifications have the capacity to respond and adapt to any extraordinary event, moreover the community participation with the governmental authorities in the decision making represents a collective management of the public green space which contributes to urban resilience by promoting citizens' capacity for learning and adaptation, and strengthen their interest and involvement in urban planning and decision making (The URBES project, 2014). Furthermore, the concept of using a limited spatial intervention in designing the parkland and to make minimal changes to the open public space supports indirectly the achievement of urban flexibility. The parkland provides various actives and functions, these include several sports and recreation facilities, the sealed areas like the former runways are used for running and cycling, some areas were designed to picnics, barbeque, and as mentioned before most of the area was left as large lawns for nature conservation. However, the park as well as includes some pioneer areas based on a oneyear contract for the local residents as urban spaces for urban agriculture and environmental education. This pioneer functions foster public participation and have a long-term perspective (The URBES project, 2014).
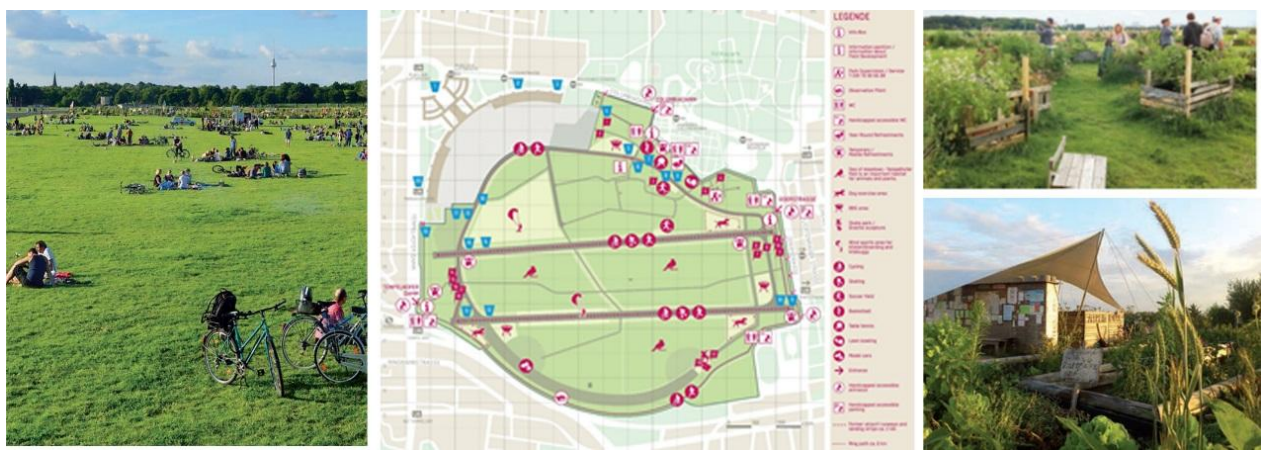

Figure 5: The current activities, recreations, and pioneer functions such as urban agriculture, source Tempelhofer Feld, 2017, edited by author

\subsubsection{Learned lessons}

The case of Berlin-Tempelhof parkland illustrates how flexible public spaces can respond and adapt to changes. Indeed urban flexibility and urban resilience are strongly liked to public spaces which considered as arenas for urban resilience and sustainability in cities. Moreover, the case showed that minimal spatial intervention can efficiently contribute to urban resilience. The case as well as represents some lessons from practice as follows:

- Due to the permeability and accessibility in designing the parkland, Tempelhof is easily 
accessible via Berlin's rapid transit system for more than 25,000 inhabitants who live within a $500 \mathrm{~m}$ distance from the park entrances and for more than 180,000 inhabitants who live within a distance of $1,500 \mathrm{~m}$. This means that around $5 \%$ of the city population can directly benefit from the ecological and recreational services provided by Tempelhof (The URBES project, 2014), thus why the parkland can efficiently contribute to urban resilience during extraordinary events.

- The case clarified that minimal spatial intervention that promotes the conservation of green open spaces contribute to the enhancement of the recreation activities for the local residents. It shows one way of contributing to urban resilience, meanwhile, it improves the well-being and the health of the community in Berlin (The URBES project, 2014).

- Indeed the parkland of Tempelhof as an exceptionally vast flexible public space (with its large open public space of 909 acres) represents a good example of design through spatial intervention for urban resilience and sustainability.

\section{Conclusion}

Based on the theoretical discussion and the two selected practical cases the study shows that there is a nexus that links flexible public spaces that were designed through spatial urban intervention and the achievement of resilient cities. However, this concept regarding the achievement of resilient cities (in terms of a whole city, not a district or limited area of the city) needs to rely on the entire public spaces network of the city and not to be limited to an individual case.

The study sets some definitions that represent a more comprehensive understanding such as the definition of what is so-called resilient city, this definition based on the broader understanding of extraordinary events which is not limited to the sudden disasters, the study states that the concept of disasters refers to all types of unpredictable and unpredictable events, in other words to any extraordinary event. Thus the resilient city is a city that managed to achieve an urban resilience capacity to face all the types of extraordinary events. Furthermore, the study discussed the need to urban flexibility as an initial inevitable feature in public spaces in order to contribute to urban resilience, the study clarified that urban flexibility shares many similarities with urban resilience, simply the term flexible can be considered as a synonymous of resilient. They share the same concept regarding a system status that has the capacity to response, cope, and adapt to new conditions. In this sense, the study can state that a resilient city is one that has a network of flexible public spaces. As well as the study discussed the criteria that mark flexible public spaces, in which these spaces are permeable and enjoy high accessibility that is not only limited to the allowance of the public to access the spaces but also to feel that they are welcome. Moreover, flexible spaces for urban resilience purposes have to be legible and smart designed in order to have the capacity to respond and adapt to any extraordinary events. Finally, the study reviewed two cases that illustrates the main argument of this study, in which, flexible public spaces that were designed through urban spatial intervention have the potentials to contribute to urban resilience in their surrounded urban context, as well as, these cases show the importance to use spatial urban intervention as a design approach that supports the community participation, which as well contributes to a more resilient community, and furthermore, the two cases 
reviled that urban resilience have many types, such as the water resilience in the Rotterdam case, where the extraordinary events are linked to stormwater events and the social resilience in the case of Berlin, where the Tempelhof Parkland through its vast flexible open public spaces contribute to various socio-economic functions for the local community in peacetime and extraordinary events, and finally, it is always less is more, the case of Tempelhof Parkland clarified that sometimes minimal urban intervention is more efficient in the creating of flexible public spaces.

\section{References}

Allan, P., \& Bryant, M. (2010). The critical role of open space in earthquake recovery: a case study, in EN: Proceedings of the 2010 NZSEE Conference, Nueva Zelandia. pp. 1-10.

Ardeshiri, M., Esteghlal, A. \& Etesam, I. (2016). Explaining the Concept of Flexibility in Urban Spaces. International Journal of Applied Arts Studies, IJAPAS Vol.1 (2016) 79-91

Bentley, I., Alcock, A., Murrain, P., McGlynn, S \& Smith, G. (1985), Responsive Environments: A Manual for Designers. London: Architectural Press.

Bacon, E. (1976). Design of Cities, New York: Penguin Books.

Beirão, J. (2011). Generative tools for flexible urban design. Project: City Induction, Business Strategy and the Environment.

Carmona, M. (2010). Public places, urban spaces: the dimensions of urban design: Routledge

Chiesura, A. (2004). The role of urban parks for the sustainable city. Landscape and Urban Planning, pp 68, 129- 38.

Christopherson S., Michie J. \& Tyler P. (2010). Regional Resilience: Theoretical and Empirical Perspectives. "Cambridge Journal of Regions, Economy and Society", No. 3.

Costa, A., (2006). Interventions in urban centers - objectives, strategies and results: review. City \& Time 2 (1): 7.

Cybriwsky, R. (1999). Changing Patterns of Urban Public Space: Observations and Assessments from the Tokyo and New York Metropolitan Area, Cities, 16(4): 223-231.

Cities Alliance, (2016). Accelerating City Resilience, Cities Alliance, cities without slums a Cities Alliance Joint Work Programme that strategically leverages global expertise, knowledge and financing to address local resilience challenges in cities.

DE URBANISTEN, (2013). Retrieved 28 April 2019 from: http://www.urbanisten.nl/wp /?portfolio= waterplein-benthemplein

Dumiak, M. (2014). Tempelhof airport in Berlin is now an ad hoc park with a wide-open future. Landscape architecture magazine, March 2014.

Elewa, A. (2019). Innovative urban interventions as an approach for livable and sustainable cities. Journal of Engineering and applied science, VOL.66, NO.3, June. 2019, PP. 355-278. Faculty of engineering, Cairo University.

Evans, M. (2019). Resilient City Overview and Urban Design Principles, building cities to withstand the challenges of the future.

Fallah, M., Masoud, M. \& Navaie, A. (2014). Role of resilient and flexible urban space in disaster Management. Bulletin of Environment, Pharmacology and Life Sciences. Bull. Environment Pharmacol. Life Sci., VOL 3 Special Issue III 2014: 01-06.

Fuentes, C., \& Tastes, M. (2015). The role of open space for urban resilience: A case study of San Pedro de la Paz under the context of the 2010 earthquake in Chile. Presented at the 7th i-Rec Conference 2015: Reconstruction and Recovery in Urban Contexts.

Giles-Corti, B. Broomhall, M. H. Knuiman, M. Collins, C. Douglas, K. et al. (2005). Increasing walking: how important is distance to, attractiveness, and size of public open space? American journal of preventive medicine, vol. 28, pp. 169-176, 2005.

Howard, E., 1898 (1965). Garden Cities of To-morrow [edited by Frederic James Osborn]. Cambridge, MA: MIT Press (first published, 1898, as Tomorrow: A Peaceful Path to Real Reform). 
ICLEI, (2017). Resilient Cities Report 2017, tracking local progress on the resilience targets of SDG 11, ICLEI - Local Governments for Sustainability, based on the proceedings of the 8th Global Forum on Urban Resilience and Adaptation4 - 6 May 2017 | Bonn, Germany.

Jayakody, C., Amaratunga, D. \& Haigh, R. (2016). The use of Public Open Spaces for Disaster Resilient Cities. Conference Paper. 12th International Conference of the International Institute for Infrastructure Resilience and Reconstruction.

Khodadad M \& Sanei M. (2017). Necessity of collaboration between technology and architectural design in order to develop the urban space quality. World Journal of Engineering and Technology. VOL.5 (04): 574 .

Lynch, K. (1960), The Image of the City. Cambridge MA: MIT Press.

Madanipour, A. (1996), Design of urban space, an inquiry into socio-spatial process, John Wiley \& Sons.

Madanipour, A. (2018). Temporary use of space: Urban processes between flexibility, opportunity and precarity. Urban Studies 2018, Vol. 55(5) 1093-1110_ Urban Studies Journal Limited 2017.

Mehta, V. (2014). Evaluating Public Space. Journal of urban design, VOL.19, 2014-Issue 1.

Molenaar, A., \& Gebraad, C. (2014). Rotterdam resilient delta city connecting water and adaption with opportunities. Water Governance- 01/2014-47.

Montenegro, M. (2010). Urban resilience. Seeds Magazine, February 16. Retrieved 28 Feb. 2019 from: http://seedmagazine.com/conent/print/urban_resilience/.

Moughtin, J. C. (2003). Urban Design: Street and Square, Third Edition 3rd Edition. Architectural Press; 3 edition (July 3, 2003).

Moreno, J. Meece, B. \& Emperador, S. (2014). A framework for using open green spaces for climate change adaptation and resilience in Barranquilla, Colombia. Green Infrastructure Analyst Resilient Cities ICLEI May 30, 2014

Müller, B. (2011). Urban and Regional Resilience - A New Catchword or Consistent Concept for Research and Practice? In: Urban Resilience: How Do Cities and Regions Deal With Change. Ed. B. Müller. German Annual of Spatial Research and Policy Series, Springer.

OECD, (2016). Resilient Cities, Policy Highlights of the OECD Report (Preliminary version). The Organization for Economic Co-operation and Development (OECD).

Petal, R. \& Nosal, L. (2016). Defining the Resilient City. United Nations University Centre for Policy Research Working Paper 6.

Polko, A. (2012). Resilience space development in the context of urban and regional resilience. Journal of Economics and management, Vol. 10, 2012

Project for Public Spaces, (2009). The Power of 10+: Applying Place making at Every Scale. Retrieved 9 April 2019 from: https://www.pps.org/reference/the-power-of-10/

Romero-Lankao, P. Gnatz, D. Wilhelmi, O. \& Hayden, M. (2016). Urban Sustainability and Resilience: From Theory to Practice. Sustainability 2016, VOL.8 (12), 1224.

Rotterdam Municipality, (2008). City of Rotterdam. Rotterdam Urban Vision: Spatial Development Strategy 2030; Rotterdam Municipality: Rotterdam, The Netherlands, 2008.

Sanei, M. Khodadad, S. \& Khodadad, M. (2018). Flexible Urban Public Spaces and their Designing Principles. Journal of Civil Engineering and Urbanism. Volume 8, Issue 4: 39-43; Jul 25, 2018.

SDUDE, (2012). From Airport to Tempelhof Parkland. Senate Department for Urban Development and Environment (SDUDE). Berlin, Germany.

Sendra, P. (2015). Rethinking urban public space: assemblage thinking and the uses of disorder. City: analysis of urban trends, culture, theory, policy, action 19 (6).

Till J \& Schneider T. (2005). Flexible housing: The means to the end. Arq: Architectural Research Quarterly. 9 (3-4): 287.

The URBES project, (2014). Urban resilience and sustainability, two sides of the same coin? The URBES project, Urban Biodiversity and Ecosystem Services.

Turan, MH. (2016). Environmental stress and flexibility in the housing process 1.5. Environmental Design Research: Volume one selected papers.

UN, (2018). The World's Cities in 2018, Data Booklet, United Nation. United Nations, Department of Economic and Social Affairs, Population Division (2018). World Urbanization Prospects: The 2018 Revision. 
UNISDR, (2010). Making cities resilient: my city is getting ready, 2010-2015 world disaster reduction campaign. The UN office for Disaster Risk Reduction. UNISDR-International Strategy for Disaster Reduction 2010.

UNISDR, (2012). How to Make Cities More Resilient. A Handbook for Local Government Leaders. The UN office for Disaster Risk Reduction. A Handbook for Local Government Leaders. A contribution to the Global Campaign 2010-2015.

Vale, L. J. (2014). The politics of resilient cities: Whose resilience and whose city? Building Research \& Information, 42(2), 37-41.

Wilkinson, T., (2017). Water Square, in Rotterdam, The Netherlands by De Urbanisten. Retrieved 14 April 2019 from: https://www.architectural-review.com/buildings/water-square-in-rotterdam-thenetherlands-by-de-urbanisten/10017644.article

Woolley, H. (2006). Freedom of the city: Contemporary issues and policy influences on children and young people's use of public open space in England. Children's Geographies, vol. 4, pp. 45-59, 2006

World Bank, (2013). Building Urban Resilience: Principles, Tools, and Practice.

Zhang, x. \& Lid, H. (2018). Urban resilience and urban sustainability: What we know and what do not know? Cities, Volume 72, Part A, February 2018, Pages 141-148

Zimmer, L. (2014). Water square Benthemplein is the World's First Public Water Park Fed by Collected Rainwater. Retrieved 12 April 2019 from: https://inhabitat.com/watersquare-benthemplein-isthe-worlds-first-public-water-park-fed-by-collected-rainwater/ 